\title{
Erotic Element in George Herbert's Sacramental Poetics
}

\author{
Dr. Veena R. Ilame
}

Assistant Professor, Department of English, A.G. College, Nagpur, Maharashtra, India

\begin{abstract}
This research paper aims at attempting to contextualisation the ambivalent erotic elements in George Herbert's Poetry within a theological account of the problem of the language-one consistent with exegetical writings of St. Augustine. It is this that, at the heart of the argument, is a hermeneutics of Faith that links the corporeality of human language to a theology of the human body as a sacrament. Reformative theology had positively identified God's redemptive purposes in human corporeality; for God had created the body in His image, assumed and suffered it through His son, Jesus Christ, and now dwells in it in the form of the Holy Spirit. It can be seen that drawn on the literal meaning of the book of Genesis and the Song of Songs in the Holy Bible; Incarnation Theology possibly asserted an early Eros that redeemed by Grace. It is true that it is not purging, nevertheless the eradicable presence of the guilt that marks a reaction to the text purely. Incapable of redemption prelapsarian sexuality without feelings of shame, the language embodies a tainted consciousness that can merely be transcended by the Grace of Divine revelation.
\end{abstract}

Keywords - ambivalent, Divine, contextualisation, erotic, elements, Herbert, poetry, revelation.

\section{INTRODUCTION}

It is this that George Herbert's language of sexuality has been the subject of ample modern critical commentary. Drawing on biblical, exegetical, and literary traditions, scholars have explored the poet's use of sensual language through two fundamental viewpoints. The first cast Herbert's religious lyrics as "sacred parodies" that artfully harness the arts of secular love poetry to the pedagogical purposes of devotional representation. ${ }^{1}$ The second view seemingly argues that Herbert's achievement demonstrates not so much redemption of age-old traditions as a recuperation of poetry's sensual origins in such divinely inspired texts as the Song of Songs. Implied in this latter "sacramental" view are the blessed continuities between the sacred and the profane, the spiritual and the sensual. Accordingly, Scripture does not merely furnish a repertoire of rhetorical tropes for expressing the nature of humandivine Love nevertheless also establishes the religious warrant for an affirmative embrace of human sexuality. Within this interpretive scheme, sexual metaphors participate in the realm of literal reality: although allied with the corruptible Flesh and the corrupt imagination, the vocabulary of human sensuality may nonetheless serve as a vehicle of heavenly Grace.$^{2}$
The analysis displays that Critics, however, have frequently been leery of Herbert's sacralisation of "profane" sensuality. Concerning Herbert's recourse to the language of sacred love poetry, Rosemond Tuve in a 1959 essay claimed that "when the Love exchanged is between God and man . . . identical words and similar phrases of profane poetry cease to bear a comparable significance."3 More recently, Anthony Low observed that "George Herbert found it difficult to accept in full the implications of the traditional biblical tropes of love and marriage, in which Christ is figured as the bridegroom and the Church or the individual Christian as the bride." ${ }^{4}$ Relatedly, Chana Bloch suspects that although the Song of Songs gave Herbert "a warrant, an associative predisposition, to visualise the Love of humanity and God in terms of an erotic relationship between a man and a woman . . . it is unlikely that he would have intended an explicitly sexual scene" in "Love" (III) and other poems. ${ }^{5}$ In arguably the frankest treatment of The Temple's erotic achievement, Michael Schoenfeldt argues for a reflexive critique that confesses rather than dismisses the anxieties that Herbert's erotic language might arouse: "In failing to acknowledge this eroticism and the uneasiness it arouses, we make Herbert's poetry the subject of our repressions." 6 Schoenfeldt's chief interest, however, is in portraying the poet's nervous engagement with the language of Christian 
eros, the better to situate The Temple within a history of ambivalent cultural and religious attitudes towards the endorsement of erotic expression. He suggests that for Herbert, sexual tropes portraying human-divine Love remain at once lawful and illicit, notwithstanding their basis in scriptural warrants. Moreover, for Herbert's Country Parson, "Romantic love and erotic desire are suppressed as refractory and irreligious forces." Indeed, where they appear in the religious contexts of The Temple, the result is a covert sense of unease for both poet and reader.

It is this that, to contextualise such ambivalent readings of Herbert's erotology within a theological account of the problem of language - one consistent with the exegetical writings of St. Augustine., at the heart of this argument is a hermeneutics of Faith that possibly associates the corporeality of human language to a theology of the human body as a sacrament. It may be that Reformation theology had identified God's redemptive purposes in human corporeality: for God had created the body in His image, assumed and suffered it through His Son, and now dwells in it as the Holy Spirit. Drawing on literal readings of Genesis and the Song of Songs, Incarnation Theology emphasised the possibility - if not the necessity - of earthly eros redeemed by Grace. Indeed, to deny the divine potentiality of the body was to reject both God's image in humankind (Genesis 1:27) and Christ's humanity. As St. Augustine declares, those who would condemn the body are themselves guilty of carnality:

For anyone who exalts the soul as the Supreme Good, and criticises the nature of Flesh as something evil, is, in fact, carnal alike in his cult of the soul and his revulsion from the Flesh, since this attitude is prompted by human folly, not by divine truth. ${ }^{8}$

Thus affirmed was a dialectical understanding of Christian eros - one that sought to balance disaffection toward the Flesh as a source of mortal corruption with affection for the body as the site of spiritual redemption. Notwithstanding its carnal inclinations, erotic language itself could be absorbed and absolved by a theology of the Incarnate Word. In this essay, I pursue the implications of this hermeneutic regarding St. Augustine's writings and their theological resonances in the poetry of The Temple. ${ }^{9}$ At the heart of Herbert's Augustinian account of sacred eroticism, I suggest, is a dialectical treatment of the holy capabilities and liabilities of poetic wit. In Thomas Hobbes's comprehensive definition, "both Fancie and Judgement are commonly apprehended under the name of Wit," which consists in "those grateful Similes, Metaphors and other Tropes, by which Poets and Orators have it in their power to make things please or displease." ${ }^{10}$ At issue for the devotional poet, however, is wit's provenance in the fallen faculties of "Fancie" and "Judgement." Puritan suspicion of poetry and the arts of rhetoric charged that wit's seductive charms emanated from carnal knowledge and the wayward imagination. For Herbert, the devotional irony is at best self-effacing, even gesturing towards prosaic "plainness," as the poet-speaker in "Jordan" (I) declares: "Nor let them punish me with loss of rime, / who plainly say, My God, My

11

King" (11. 14-15). Similarly, the preacher's oratory, according to Herbert's Country Parson, ought to be humbled by piety, since "the character of his Sermon is Holiness; he is not witty, or learned, or eloquent, but Holy."12 Nevertheless, "wit" remains the central dynamic of Herbert's sacred art - a paradox that his poems brilliantly enact through a sacramental poetics of human sexuality. Consistent with Reformation spirituality, Herbert's poems pursue the thesis that both sexuality and textuality, however inherently corrupt, remain worthy of spiritual regard. Both the mortal body and carnal language are redeemable by Grace when consecrated to devotional ends.

Throughout its interpretive history, the Christian language of eros has been the locus of interpretive anxiety. Wary of complex heavenly realities with bodily experiences, patristic discussions of the Song of Songs in the Middle Ages and the Renaissance frequently cautioned against interpretations wrought by fleshly passions. ${ }^{13}$ Referring to the Song's explicit descriptions of the lovers' bodies, the Protestant James Durham declared that "our Carnalness makes it hazardous and unsafe, to descend in the Explication of these Similitudes."14 Martin Luther decries not only man's inability to relive the felicitous sexuality of Edenic innocence, but also his incapacity to apprehend it through language. Inevitably, by registering prelapsarian reality through postlapsarian communication, "we continually experience the opposite, and so we hear nothing but bare words." 15 Yet, apart from silence, it is "bare words" that the devotional poet must be content to work with. ${ }^{16}$ At issue, then, is a language of accommodation that can only adumbrate, but never fully embody, the untainted sexuality of a prelapsarian past.

"How shall infection / Presume on thy perfection?" (11. 3536) the speaker of "Miserie" asks. The answer, I suggest, lies in the poet's artful exposition of an Augustinian hermeneutic that situates the problem of human sexuality within the broader problematic of devotional representation. If it is the language that must express the Love between creature and Creator, then it is language's 
expressiveness that cannot be divorced from one's knowledge of Love. As James Turner suggests, "In Augustine's Christianization of Platonic Eros, the love impulse is a force at once erotic, hermeneutic, and ontological." 17 This essay argues, then, that a theologically sensitive reading of The Temple's erotic tropes must attend to the anxious relations between devotional expression and interpretation. Throughout, the continuities and contradictions between "fallen" and "redeemed" sexuality will be seen to parallel the tensions between the promises and pitfalls of poetic inscription. A curious paradox emerges: for it is only by acknowledging the "infections" of the concupiscent imagination that we may begin to imagine the "perfections" of a divine love to which language can only gesture.

\section{EROS IN THE GARDEN}

In their attempts to comprehend the divine origins of human sexuality, medieval exegetes returned to Scripture's opening narrative of the Fall. St. Augustine argued that first Love consummated in the Garden would have combined sensual ecstasy and spiritual purity. While the Fall marked the primal conception of "carnal knowledge" and lust, all prelapsarian sexual activity was otherwise a conscious expression of worship coupling human sensual experience with heavenly Love. Both curse and cure, fallen sexuality became the instrument of humanity's redemption through Christ the second Adam - a promise foretold in the divine injunction to "be fruitful and multiply" (Genesis $1: 28) .{ }^{18}$ In the divine prescience of the "fortunate fall," sex's double-edged sword assured at once the continuity of original sin and the perfection of human salvation. ${ }^{19}$

According to Augustine, the primal act of transgression witnessed the coupling of man's disobedience to God with the revolt of his Flesh. In a parodic re-enactment of Adam and Eve's primal act of rebellion, erotic emotions after the Fall was no longer subject to voluntary control but given over to spontaneous arousal in defiance of reason. Indeed, "So intense is the pleasure that when it reaches its climax, there is the almost total extinction of mental alertness; the intellectual sentries, as it were, are overwhelmed." 20 Augustine suggests that it was the shame at seeing their genitals uncontrollably aroused that led Adam and Eve to cover their loins with fig leaves. The twelfth-century saint, Albert the Great, likewise explains:

When Adam first withdrew from God, his body was also corrupted and not subject to the soul. Sensual motion, infused with the serpent's venom, was so put off track that in its movements it did not obey, particularly regarding sexual pleasures ... Consequently, it was in the motion of the genitals that they [Adam and Eve] were first conscious of their nudity. ${ }^{21}$

As Michael Schoenfeldt notes concerning Isaiah 47:3 ("Thy nakedness shall be uncovered, yea, thy shame shall be seen") and Rev. 16:15 ("Blessed is he that watcheth, and keepeth his garments, lest he walk naked, and they see his shame"), pudendum, the Latin equivalent for "shame," signifies both "the external genitals" and "the shameful parts of something" $(O E D 1,2) .{ }^{22}$ It is this shameful lust which "thickens all [his] powers" that the speaker in "Sighs and Grones" wishes to hide from sight as if recalling the scene of disgrace in the Garden:

O do not blind me! I have deserved that an Egyptian night

Should thicken all my powers; because my lust

Hath still, sow'd fig-leaves to exclude thy light. (11. 13-16)

In "The Pearl," the insurgent flesh decries itself, even as the object of the speaker's lament: "My stuff is flesh, not brass; my senses live, / And grumble oft, that they have more in me / Than he that curbs them" (11. 27-29). In "Dulnesse," the speaker's wayward Flesh, possessed by its own will, engenders "surged lyes" that mock the sinner's attempts to expose them:

But I am lost in Flesh, whose surged lyes Still mock me, and grow bold:

Sure thou didst put a mind there if I could

1. Find where it lies. (11. 21-24)

Throughout The Temple, Herbert explores the theological links between desire and pride through a sustained pattern of horticultural images hinting at priapic aggression. In "The Flower," a postlapsarian garden threatened by storms and frosts provides the setting in which the spiritually aspiring speaker appears as one of many young shoots that "shoot up fair" (1. 24) to "grow in a straight line, / Still upwards bent" (11. 29-30). Here the phallic charge of the speaker's "growing and groaning thither" toward a "springshower" (11. 25-27) is reinforced by the engorged image of human pride: "Who would be more, / Swelling through store, / Forfeit their Paradise by their pride" (11. 47-49). ${ }^{23}$ God's anger finally rebuffs such mortal striving:

But while I grow in a straight line,

Still upwards bent, as if heaven were mine own, Thy anger comes, and I decline. (11. 29-31)

The oxymoron "upwards bent" suitably captures the futility of human ambition. "Bent" equivocates on the meanings of "determined" and "deflected," as if conjoining the persistence of the will with the imminence of its mortification. Significantly, the $O E D$ assigns horticultural meanings to the noun bent dating back to the late fifteenth 
century: "A name given to grass of a reedy or rush-like habit, or which has persistent stiff or rigid stems; also to various grass-like reeds, rushes, sedges, and other plants." "In "The Flower," such bents that "shoot up" while "growing and groning" (11. 24-25) contain within themselves the punitive seeds of libidinal excitement, for as Herbert cautions in the Williams manuscript version of "The Church-porch": "Lust . . . is a rodd / Whose twigs are pleasure, \& they whip thee bare" (11. 8-9). As I will attempt to show, the priapic valence - and violence - of rods, reeds, twigs, and similar plant imagery will be revisited with calculated significance throughout The Temple.

Where gardens grow, man's unruly members lurk. The spectre of fallen sexuality similarly haunts the postlapsarian landscape of "The World":

Then entered Sinne, and with that Sycomore,

Whose leaves first sheltered man from drought \& dew, Working and winding slily evermore,

The inward walls and Sommers cleft and tore:

But Grace shor'd these and cut that as it grew. (11. 11-15)

As Don Cameron Allen notes, the "Sycomore" alludes to the fig tree that appears throughout Scripture with ominous warnings. ${ }^{25}$ "Working and winding slily evermore," the leaves of the tree recall Adam and Eve's naked shame in the aftermath of their encounter with the serpent's "slippery body, moving along in tortuous twists and turns." 26

In Herbert's symbolic ecology, trees are rooted in the lost Garden of Eden. Robbed of its forbidden fruit, the Tree of Knowledge stands witness to humanity's fallenness. The accused subject of the poem "Man" is "a tree" - one that "yet bears no fruit" (1. 8). The despairing speaker in "Obedience" asks, "Lord, what is the man to thee, / that thou shouldst mind a rotten tree?" (11. 21-22). In "Affliction" (V), humans are "the trees, who were shaking fastens more, / While blustering windes destroy the wanton bowers" (11. 20-21). Throughout The Temple, the fallen tree that is Man stands as an image of sinful pride and disobedience intimately associated with priapic lust. ${ }^{27}$ In "Faith," fallen "creatures [that] had no real light / Inherent in them" (1.33) appear to have once dwelt in

That which before was darkened clean with bushie groves, pricking the lookers eye, Vanisht away, when Faith did change the scene: And then appeared a glorious sky. (1l. $37-40)$

Like the "wanton bowers" of "Affliction (V)," these "bushie groves" threaten to "prick" the "lookers' eye" (1. 38). Notably, the $O E D$ entry for the noun "prick" dates the earliest coarse references to "penis" to 1555 and 1592 - a pun that Herbert's use of the verb form might well have exploited. ${ }^{28}$ In "Frailty," the world's meretricious "Regiments," cloaked in "glory and gay weeds, / Brave language, braver deeds," turn to dust, only to "quickly rise / And prick my eyes" (11. 13-16). Suggestively, in the Williams manuscript, the original line 16 "Troubling mine eyes" had been amended in the poet's hand to read "And prick mine eyes." 29 What "troubles" or "pricks" the eye, then, is the "planting" of an idolatrous tower in the soul of the speaker who has "long since Wed" his "poor soul, even sick of love" (1.21) to his Savior:

Affront those joys, wherewith thou didst endow

And long since Wed My poor soul, even sick of Love:

It may a Babel prove

Commodious to conquer heaven and thee

2. He planted in me. (11. 19-24)

"As a symbol of upward striving," Janis Lull asserts, "Babel unquestionably held a guilty sexual charge for Herbert." 30 Enacting humankind's hubristic attempts at assailing the heights of heaven, the Shemites' rebellious erection of the Tower in Genesis 11 may be seen to mirror the recalcitrant priapism of Adam's punishment. Moreover, the Fall of Babel was a catastrophe of the profound linguistic moment, for the proliferation of languages that was God's judgment had deepened the epistemological gulf between words and things. The myth of Babel writes Gerald Bruns, “duplicates the story of man's fall from the harmony of his original paradise typologically by dramatising the fall of the word from its original harmony with the world." 31 The original/original speech act, through which God spoke the world into existence, was typologically repeated in the account of Genesis 2:19-20; then, human language uttered by Adam as he named every living creature had been divinely commissioned to conceive univocally of the things they called. Ever since the Fall, however, the history of metaphor - of the Word as a signifier - has witnessed, according to Jacques Derrida, "a progressive erosion, a regular semantic loss . . . an empirical abstraction without extraction from its native soil." 32 Rising amid the erosion of ties between mortal signifiers and their spiritual signifieds, then, was a fallen, poststructuralist order - a world of disorderly signs governed by the indeterminacy of signification.

As Herbert observes in his Latin poem "Memoriae Matris Sacrum," with "language being chaos since / The time of Babel" ("Nam post Babelum linguae adest confusion" [1. 13]), ${ }^{33}$ what more can devotional poetry do but acknowledge its cooperation with the postmodern crisis of representation? "We say amiss, / This or that is: / Thy word 
is all if we could spell" ("The Flower," 11. 19-21). On this view, language's duplicity becomes the underlying concern of the poem "Frailty," where the contrast between surface and substance turns on the fragility of signification:

Lord, in my silence how do I despise What upon Trust

Is styled honour, riches, or right eyes; But is good dust!

I surname them guided clay,

Deare earth, beautiful grass, or hay;

In all, I think my foot doth ever tread

3. Upon their head. (11. 1-8)

The art of naming spells deception in a world of discursive realities, where the italicised words "honour, riches" and "fair eyes" might just as well be "surname[d] . . guided clay / Deare earth, fine grass, or hay." As the speaker confesses, it is precisely in "silence" that he can "despise" the mere affectations of words as "Brave language, braver deeds" (1. 14), whose joys "may a Babel prove" (1. 22). The crumbled ruins of the Tower, symbolising the dissolution of the primal unity of language and reality, Word and world, become the "dust" that "doth quickly rise" to "prick" (1.15) the eyes in a motion of phallic assault.

Language's will to exceed the bounds of authorial intention - in a word, its vulnerability to plural interpretations further implicates the fallen libido's willful desertion of conscious control. Indeed, the crisis of language is bound up with the dilemma of human sexuality strikes at the heart of The Temple's erotic concerns. Titled "Invention" in the Williams manuscript, "Jordan" (II) pictures poetry's desire for "quaint words and trim invention" (1. 3) in the sexualised motif of botanical images that "burnish, sprout, and swell" (1. 4). As if recalling the ornate spiral structures of the Tower of Babel in Pieter Bruegel's 1563 painting, ${ }^{34}$ the speaker's thoughts, "Curling with metaphors a plain intention" (1. 5), revolve into a whirl of fire: "As flames do work and winde, when they ascend, / So did I weave my self into the sense" (1l. 13-14). The theme of man's selfswirling vanities recurs in other poems that recall a similar motif. In "The Pearl," the tempting "wayes of Learning," "Honour," and "Pleasure" (11. 1, 11, 21) resemble "labyrinths" from which "grovelling wit" (1. 37) affords no escape. A sacred parody of Ariadne's thread, God's "silk twist" is that saving Grace by which sinners may be led to heaven:

Yet through these labyrinths, not my grovelling wit,

But thy silk twist let down from heaven to me,

Did both conducts and taught me, how by it

4. To climb to thee. (11. 37-40)
According to John Calvin, "each man's mind is like a labyrinth," just as the "divine countenance ... is for us like an inexplicable labyrinth unless we are conducted into it by the thread of the Word." ${ }^{35}$ As if "in wand'ring mazes lost" with the fallen angels of Milton's Paradise Lost, ${ }^{36}$ Herbert's speaker in "A Wreath" pleads for an escape from "My crooked winding ways, wherein I live, / Wherein I die, not live" (11. 4-5).

In the poem "Sinnes round," the twisting motions of a rising "Babel" revolve into a reflexive portrayal of the circular ties between linguistic cupidity and libidinous sexuality:

My hands do join to finish the inventions:

And so my sinners ascend three stories high, As Babel grew before there were disagreements.

Yet ill deeds loiter not: for they supply

New thoughts of sinning: wherefore, to my shame,

Sorrie I am, my God, sorrie I am. (1l. 13-18)

As Michael Schoenfeldt notes, "self-involved writing and masturbatory desire . . . are so intertwined in 'Sinnes Round' that it is difficult to tell whether writing functions as a metaphor for masturbation or masturbation a metaphor for writing." ${ }^{37}$ The metaphor of linguistic onanism insinuates itself in the intercourse between the speaker's "inflaméd thoughts" (1. 6), his hands' "inventions" (1. 12), and his words' ejaculatory fires: "My words take fire from inflaméd thoughts, / which spit it forth like the Sicilian hill" (11. 7-8). As the Tower's erect pride images the errant pen and erring penis, so the speaker laments, "words suffice not, where are lewd intentions" (1. 11). Allegorised in the chiasmic repetition of each stanza's first and last line is the self-perpetuating motion of a kind of poetic autoeroticism. Mirroring the intractable nature of man's genital movements, the waywardness of the fallen imagination wit's "unruly engine" ("Perirrhanterium," 1. 241) exemplifies, according to Richard Strier, "the peculiar independence of thoughts from the conscious direction, a phenomenon which Herbert found deeply disturbing." ${ }^{38}$ As Calvin admonishes:

Man's mind, full as it is of pride and boldness, tries to imagine a god according to its capacity ... To these evils new wickedness joins itself, that man tries to express in his work the sort of God he has inwardly conceived. Therefore the mind begets an idol; the hand gives it birth. ${ }^{39}$

Janis Lull observes that "Herbert conceived intimate links between all forms of pride, whether overt or covert and fallen sexuality. He saw this corrupt desire poisoning all human deeds, including the writing of poems." ${ }^{40}$ As we have seen, the dialectical relations between wit and lust, 
writing and desire, play out in a pattern of sexually charged imagery in several poems where wit's refractory will is allied to male sexual aggression. In a suggestive allusion to this notion of masculine violence, Izaak Walton writes that Herbert had ascribed his physical infirmities during his studies at Cambridge to the piercing effects of his pen's exertions: "He had too thoughtful a wit: a wit, like a penknife in too narrow a sheath, too sharp for his body." ${ }^{41}$ In the sexual subtext of Herbert's poems, the pen is a "knife" that wields an uncircumcised wit - a pen (is) knife whose inscriptions and incisions expose the lust of the creative imagination. ${ }^{42}$ Like the predatory scientists in "Vanitie" (I), the astrologers of "Divinity" unleash a similarly "masculine" assault on nature, "Which with the edge of wit they cut and carve". At the same time "Reason triumphs and faith lies by" (11. 7-8).

Drawing on the exegetical association of circumcision with the taming of unruly sexuality, Schoenfeldt contends that "The frequent identification of the erect penis with sin, rebellion, and aggression in Herbert's poetry can be understood at least in part by reference to

Renaissance discourse about the ritual of circumcision." ${ }^{43}$ The poem "Paradise" analogises the process of linguistic circumcision, whereby words themselves undergo morphological "pruning":

When thou dost more significant judgments SPARE

And with thy knife but prune and PARE,

Ev'n fruitful trees more fruitful ARE. (11. 10-12)

In a sermon on Genesis 17:24, John Donne, too, employs horticultural metaphors when describing circumcision as "an Excession, cutting off the root, and branch, the Sinne, and the fruits, the profits of that sinne." 44 Whereas Donne in "The Crosse" entreats his Savior to "Crosse and correct concupiscence of wit" (1. 58), ${ }^{45}$ Herbert takes matters into his own hands. Exploiting the homologies between the poet's pen, the gardener's knife, and the branches of unruly plants, the poet of "Paradise" figures the redemptive "pruning" of his poetic wit through the orthographic excision of morphemes and phonemes.

Throughout The Temple, the association of writing tools with the threat of pointed instruments is subtle but continuous. Janis Lull notes the sexual suggestiveness of "strain" and "consort" in a passage from "Employment" (I) - "Lord, place me in thy consort: give one strain / To my poor reed" (11. 23-4) - and suggests that "The reed, 'poor' or not, is another symbol of male egotism - at once phallus, musical instrument, and pen." 46 In "The Churchporch," the opening lyric of the Williams manuscript,
Herbert explicitly adverts to the dangers of lust and its illicit links with Christ's botanical instruments of torture:

Beware of Lust (startle not) o beware

It makes thy soul a blott: it is a rodd

Whose twigs are pleasures, \& they whip thee bare,

It spoils an Angel: robs thee of thy God. (11. 7-10)

The imagery of priapic plants culled from a fallen garden again underscores the clash of verse and violence in "The Sacrifice," where Christ's "wittie" persecutors "flout" him with "reeds" and mocking "ditties": "Servants and abjects flout me; they are wittie: / Now prophesie who strikes thee, is their dittie" (11. 141-42). Like his selfish ambitions, "man's scepters are as frail as reeds, / And thorny all their crowns, bloudie their weeds" (11. 177-78). Sharpened with the wit of human vanity, these "reeds" and "bloudie . . . weeds" are metonymic representations of Jesus' crown of thorns. The homologies between scourging devices, gardening implements, and the wooden crucifix emerge as well in Herbert's Latin poem "In Clauos" ("On the nails"):

Qualis eras, qui, ne melior natura minorem Eriperet nobis, in Cruce fixus eras;

Iam meus es: nunc Te teneo: Pastórque prehensus Hoc ligno, his clauis est, quasi Falce suâ.

[What a wondrous being you were, who,

Lest the God-nature rip away

The human from us, were pinned on the cross.

Now you are mine, I hold you now:

By this wood, the Shepherd has been seized,

And by these nails - as by his own

Pruning hook. $]^{47}$

The wounding-by-inscription of the "corpus-text" was doubtless a familiar trope in Herbert's time. Meditating on the literal meanings of the "Word-made-flesh," Christian writers in the Middle Ages and the Renaissance contributed to a version of the ostentatio vulnerum that saw the somaticization of the written text as marking the divine Incarnation of language. For example, in an early sixteenth-century sermon by the bishop of Rochester John Fisher, St. Francis of Assisi is described to have received stigmatic wounds upon reading the depiction of Christ's passion in the scriptures - a body of text in which the "two boards of this booke is [sic] the two parts of the crosse, for when the booke is opened \& spread . . the leaves of this booke be the armes, the handes, legges, and feete." 48 Herbert skillfully appropriates such medieval iconography, boldly infusing them with sexual resonances. This is perhaps best exemplified in the poem "The Bag," in which 
Christ's body is pierced by the combined instruments of writing and rape. As Schoenfeldt suggests, "The Bag" dramatises the kenosis of Christ as a divine strip-tease in which His body, "undressing all the way" (1. 12) to earth, is assaulted by a soldier's "spear" that transfigures His wound into a womb-like $\operatorname{sac}(\mathrm{k})$ - the titular bag. In a covertly coital gesture, the naked Jesus invites his supplicants to insert their penned desires "very

49 neare [his] heart," assuring them that their words "shall safely come":

If ye have anything to send or write, I have no bag, but here is room: Unto my Father's hands and sight, Beleeve me, it shall safely come.

That I shall minde, what you impart;

Look, you may put it very neare my heart. (11. 30-36)

Whereas Schoenfeldt conceives of the "bag" as "a kind of vaginal orifice" belonging to a feminised Christ, Richard Rambuss contends that this receptacle might equally resemble "a kind of scrotum," such that the soldier's spearing evokes not merely an image of impregnation, but also a scene of homoerotic penetration. ${ }^{50}$ As in Herbert's "Artillerie," God and the poet whose "tears and prayers night and day do woo" (1. 19) are "shooters both" (1. 25). Reflected in a diverse body of "traditional" historical and New Historicist scholarship, contesting articulations of gender and sexuality in "The Bag" offer a paradigmatic instance of the interpretative contradictions and questions begged by the very act of writing. ${ }^{51}$ What follows is a further exploration of this theme through an Augustinian reading of the troubled nexus between authorial intention and reader reception. The point I wish to demonstrate is that Herbert's sacramental erotics registers not so much the cupidity of sensual experience as the culpability of mortal language in the act of interpretation.

\section{WRITING THE CONCUPISCENCE OF WIT}

A central theme in The Temple is the poet's ambivalence over the devotional capacities and liabilities of poetic wit. Whereas secular comedian had its lawful uses in the secular offices of oratory, religious humour was properly self-effacing in its repudiation of "quaint words, and trim invention" ("Jordan" [II], 1. 3). "Nor let them punish me with losse of rime," declares the poet-speaker in "Jordan" (I), "Who plainly say, My God, My King" (11. 1415). Arising from the fallen faculties of "Judgement" and "Fancie" is wit's propensity for self-advertisement. Yet, an inescapable paradox marks the poet's attempts to disavow his "wit" by avowing its inherent pretensions. ${ }^{52}$ As Thomas Merrill notes, a mode of critical reflexivity characterises numerous poems in The Temple that strive to "disrupt their order, critique their clichés, re-invent themselves, and promote a spiritually-salutary humiliation of the "self." "53 In "The Forerunners," the poet-speaker, lamenting the ageing of his creative faculties, discovers that to be genuine "wittie" is to surrender his "dittie" to God's pleasure:

\section{So Thou art still my God be out of fear.}

He will be pleased with that dittie;

And if I please him, I write fine and wittie. (11. 10-12)

A possible pun on "art" in line 10 anticipates the poem's sacramental thesis: that poetic art renders its means worthy by surrendering its ends to godly worship. Entailed in this sacrifice of praise is a ritual cleansing of lyrical wit:

Farewell sweet phrases, lovely metaphors.

But will ye leave me thus? When ye before

Of stews and brothels only knew the doors,

Then did I wash you with my tears, and more, brought you to Church well drest and clad:

My God must have my best, ev'n all I had. (11. 13-18)

The penitent speaker/poet desires his "Lovely enchanting language" (1. 19), tainted by the world's seductions, to be "wash[ed] ... well drest and clad." The biblical allusion is fully recounted in the poem "Marie Magdalene," where the New Testament saint dissolves her worldly ties with "stews and brothels" through tears shed at Christ's feet:

Deare soul, she knew who did vouchsafe and deigne

To bear her filth; and that her sinnes did dash

Ev'n God himself: wherefore she was not loth, As she had brought wherewith to stain, So to bear in wherewith to wash:

And yet in washing one, she washed both. (11. 13-18)

The sacramental ablution of worldly language is a familiar trope that Herbert's Country Parson invokes also:

The Holy Scriptures. . . condescends to the naming of a plough, a hatchet, a Bushell, leaven, boyes piping and dancing; shewing that things of ordinary use are not only to serve in the way of drudgery, but to be washed, and cleansed, and serve for lights even of Heavenly Truths. ${ }^{54}$

Vulgar objects thus qualify for divine uses when sacrificed upon the altar of praise. Augustine, following Plato, argued that all desires were either good (caritas) or bad (cupiditas or concupiscentia) according to whether or not they were consecrated to devotional ends. Reformation theologians, moreover, insisted that caritas could not be exercised apart from the surrender to Grace, so that the poet's attempts to 
"mount" heaven rest paradoxically on "bended knee" ("The H. Scriptures" [I], 1. 14). In "Praise" (I), the poetspeaker, confessing that "To write a verse or two, is all the praise / That I can raise" (11. 1-2), ejaculates, "O raise me then!" (1. 17). The lesson is reprised in the poem aptly titled "Submission": "How to know I, if thou shouldst me raise, / That I should then raise thee?" (11. 13-14).

In the first of two sonnets dedicated to Herbert's mother, the poet speaker asks, "Cannot thy love / Heighten a spirit to sound out thy praise / As well as any she?" (11. 6-8). Here the sexual-spiritual link latent in the association of seminal ejaculation with the "expense of spirit" in Renaissance physiology recalls Jonathan Goldberg's provocative suggestion that The Temple's subtitle, "Sacred Poems and Private Ejaculations," discloses a "site of masturbation. ${ }^{55}$ Francis Bacon, linking the lust of the eyes with spiritual blindness, counsels that "much use of Venus doth dim the sight" and that "The cause of dimness of sight ... is the expense of spirits." ${ }^{56}$ In Herbert's sonnet, the bawdy pun on "heightened spirits" intimates the Holy Spirit's power to return secular love poetry to sacred ends, as if to restore sacred dignity to sexual virility. In both poems, the sexual thrust of "raise" and "rise" images a redeemed eros "raised" above its carnal afflictions by a higher Love. In An Apology for Poetry, Sir Philip Sidney declares that the "erected wit maketh us to know what perfection is, and yet our infected will keepeth us from reaching unto it." 57

In "Love" (I), the arts of secular love poetry are likened to a game of flirtation in which "Wit fancies beautie, beautie raiseth wit" (1. 9). But it is only "Immortal Love," Herbert contends, that can raise the efforts of the devotional poet, whose spiritual offices have since been usurped by the sonneteers of "mortal love." Here again, the charge is not against wit and sexual passion per se, but the uses to which they are applied. "Love" (II) likewise reclaims these sacred purposes by exalting the "greater flame" of God-centered devotion above "usurping lust" (1. 10). Crucial to the sacramental nature of all sensuous experience, then, was the alignment of sensuous enjoyment with spiritual engagement. For only by tempering his verses in the fires of "Immortal Heat" can they be quenched of carnal passions: "Then shall our hearts pant thee ... And therein, hymns send back thy fire again" (11. 6-8).

\section{THE SHAME OF INTERPRETATION}

What it has been called Herbert's sacramental erotic, based on an Augustinian reading of Incarnation theology, finds its consummate expression in "Love" (III). The Temple's concluding lyric. In the poem's central scene of tension, the speaker's guilty inclination to "drawback" from his host's invitation manifests a kind of performance anxiety, where his impulse is to "grow slack / From [his] first entrance in" (1l. 3-4). In Augustine's appraisal, erectile failure is of a piece with man's carnal propensities, for the bodily effects of the Fall were manifest not only in sensual intemperance but also in sexual impotence:

Not even the lovers of this kind of pleasure are moved, either to conjugal intercourse or to the impure indulgences of vice, just when they have so willed. Sometimes the impulse is an unwanted intruder, sometimes it abandons the eager lover, and desire cools off in the body while it is at boiling heat in mind.$^{58}$

Asked if he "lack[s] anything" (1. 6), the lover in "Love" (III) contemplates his unworthiness as if echoing the speaker in the poem "Dulnesse": "Why do I languish thus, drooping and dull" (1. 1)? Embarrassed by his double "lack" of sexual potency and righteousness (for which he is "guilty of dust and sinne"), he averts his eyes from his lover's ("Ah, my deare, I cannot look on thee" [11. 9-10]), just as Adam and Eve had hidden from God when "the eyes of them both were opened, and they knew that they were naked" (Genesis 3:7). Nevertheless, the divine lover draws nearer and, like the Holy Spirit in the poem "Easter," offers to "bear a part, / And make up our defects with his sweet art" (11. 17-18). A poetics of recuperation, dramatised throughout The Temple, thus resolves the crisis of representation in "Love" (III), where sex and text are finally wedded. In the poem's final stanza, the relations of sexuality, textuality, and spirituality culminate in the play of words and voices around a Eucharistic drama. The sexual connotations of "shame," "serve" and "meat" carry the courtship ritual through to the poem's conclusion, where the speaker's coming to "know" in the final stanza brings to a climax his erotic encounter with Love: ${ }^{59}$

And know you not, says Love, who bore the blame?

My deare, then I will serve.

You must sit down, says Love, and taste my meat:

1. So I did sit and eat. (11. 15-18)

Echoing Luke 12:37 ("he shall gird himself, and make them sit down to meat, and will come forth and serve them"), the poem's resolution images the fusion of gustatory and sexual desire embodied in Eucharistic doctrine. Ruminating on the Incarnation, the poet of "Love" (III) imagines the consummation of Love as a consuming of Flesh redeemed by the Word.

The mutuality of sex and text is even more subtly emblematised in the utterance, "My deare, then I will serve" (1. 16), whereby both religious and carnal meanings 
of "to serve" are proffered by an interlocutor whose identity in the dyadic exchange appears almost undecidable, given the referential ambiguity of the pronouns "My and "I" in the absence of speech tags. At first blush, it is the speaker who is humbly professing his desire to "serve" the God whom he affectionately calls "My deare." But in the poem's Eucharistic setting, Christ, too, is the host who "serves" his "deare" speaker the sacraments of His body and blood. Thus, the speaker, as "guest" of the communion Host, is simultaneously the "host" who invites Christ into his body's holy Temple. The (con) fusion of identities figures the consummation of "one flesh" through the consumption of the Eucharist.

In "The Banquet," a similar "double-voicing" of subject positions can be heard in the invitational couplet: "Welcome sweet and sacred cheer, / Welcome deare" (11. 1-2). The speaker who welcomes the heavenly host becomes the host who welcomes his guest. In "Love" (III), the drama of sexual solicitation and social submission joins "masculine" authority with "feminine" hospitality. At the same time, the reciprocal act of "serving" underscores the dissolution of sexual and social boundaries between the two hosts/guests. As in the poem "Clasping of hands," their gestures of mutual surrender elide all differences between "Thine and Mine," Self and Other:

Since thou in death wast none of thine, Yet then as mine didst me restore.

O be mine still! Still make me thine!

Or instead, make no Thine and Mine! (11. 16-20)

\section{CONCLUSION}

To sum it possible to argue that Augustine's meditation on shame leads him to a persistent paradox: even sex within the lawful bounds of marriage "longs to become known; and yet it blushes to be seen .... This right action craves for recognition in the light of the mind's understanding, but it is equally concerned to escape the light of the eye's vision." 69 Similarly, the reader of "Love" (III), while enticed by the poem's sacred eroticism, is seemingly embarrassed by what he or she sees to be its unseemly audacity. Like Stanley Fish's involved reader of Paradise Lost, the reflexive reader of "Love" (III) is "left to ponder the discrepancy between his response and the purity of the action."70 Indeed, the very epistemological categories that frame our interpretive lenses are themselves constitutive of our captured imaginations: "Ordinary humanity cannot look at Adam and Eve as they first looked at each other, naked and unashamed - or rather, neither naked nor clothed, since this opposition of concepts did not yet even exist." $" 71$ This reading runs counter, then, to Greg Crossan's contention that "The point of the analogy is that both physical and spiritual love require a purgation of guilt-feelings before there can be consummation or atonement (atonement). ${ }^{\prime 72}$ Indeed, it is not the purging but the ineradicable presence of guilt that marks the reader's only response to the text. Incapable of reimagining prelapsarian sexuality without feelings of shame, language embodies a tainted consciousness that can only be transcended by the Grace of divine revelation. In Reformation terms, such knowledge, also inspired by the inner counsel of the Holy Spirit, lies at the heart of Herbert's sacramental erotics. It is this that, then, resolves the drama of Grace in "Love" (III): as a critic of his actions that are mirrored in the speaker's, the reader, at last, is persuaded to surrender all anxieties to the God who bids him come, sit, and taste his meat.

\section{And extensions. Notes}

5. See, for example, The Poetry of Meditation:,;. On the conflicting meanings of "parody" to the interpretive tradition of Christian eros, see Lissa Beauchamp, "Herbert's The Temple and the Heritage of Erotic Exegesis," George Herbert Journal 24 (Fall 2000/spring 2001): 1-18.

6. On the sacred appropriateness and appropriations of physical phenomena in Herbert's language of humandivine communion, see Terry G. Sherwood's chapter, "Tasting and Telling Sweetness," in Herbert's Prayerful Art (Toronto: University of Toronto Press, 1989), pp. 5776. A recent wide-ranging discussion of the Neo-Platonic commerce between sensuous beauty and spiritual reality may be found in Anne-Marie Miller Blaise, " "Sweetness ready Penn'd': Herbert's Theology of Beauty," George Herbert Journal 27 (fall2003/spring2004): 1-21. For religious and historical examinations of the intersection between the sexual and spiritual, see, for instance, the essays collected in George Herbert: Sacred and Profane, ed. Helen Wilcox and Richard Todd (Amsterdam: VU University Press, 1995). On the theological debates over Scripture's literal and metaphorical senses, see Charles Davis, Body as Spirit: The Nature of Religious Feeling (New York: Seabury Press, 1976); and Stanley Stewart, The Enclosed Garden: The Tradition and the Image in Seventeenth-Century Poetry (Milwaukee: The University of Wisconsin Press, 1966).

7. Anthony Low, “George Herbert: 'The Best Love,' "Renascence 45 (1993): 159.

8. Chana Bloch, Spelling the Word: George Herbert and the Bible (Berkeley: University of California Press, 1985), p. 111. 
9. Michael C. Schoenfeldt, Prayer and Power: George Herbert and Renaissance Courtship (Chicago: University of Chicago Press, 1991), p. 231.

10. Schoenfeldt, Prayer and Power, p. 253.

11. Saint Augustine, Concerning the City of God Against the Pagans, trans. Henry Bettenson (London: Penguin Books, 1984), 14.5, p. 554.

12. We know that St. Augustine's works were among the books cited inHerbert's will. See "The Will of George Herbert," in The Works of George Herbert, ed. F.E. Hutchinson (1941; corr. rpt. Oxford: Clarendon Press, 1945), p. 382. Much critical commentary has been devoted to the influence of Augustine's thought on Herbert's writings. For examinations of Herbert's poetic language concerning Augustinian theories of verse and devotional representation, see Anthony Mortimer, "Words in the Mouth of God: Augustinian Language-Theory and the Poetics of George Herbert," in On Poetry and Poetics, vol. 2, ed. Richard Waswo (Tübingen: G. Narr, 1985), pp. 31 43; Richard Todd, The Opacity of Signs: Acts of Interpretation in George Herbert's The Temple (Columbia: University of Missouri Press, 1986); and William H. Pahlka, Saint Augustine's Meter and George Herbert's Will (Ohio: Kent State University Press, 1987).

13. Thomas Hobbes, Humane Nature: or The Fundamental Elements of Policy (1640), chap. 10, sect. 4; quoted in Sam Westgate, "George Herbert: 'Wit's an Unruly Engine,' " Journal of the History of Ideas 38 (1977): 284. Westgate offers an illuminating discussion of Herbert's poetic art about Hobbes's nuanced definition of "wit."

14. Unless otherwise specified, all quotations from Herbert's writings are from

The Works of George Herbert, ed. F.E. Hutchinson (1941; corr. rpt. Oxford: Clarendon Press, 1945). Line numbers reference poems throughout my essay. 12. Herbert, Works, p. 233.

13. The exegetical controversies among medieval and Renaissancetheologians over the heightened realism of the Song of Songs are discussed in George L. Scheper, "Reformation Attitudes toward Allegory and the Song of Songs," PMLA 89 (1974): 551-62.

14. He quoted in Scheper, "Reformation Attitudes," p. 557.

15. Martin Luther, Lectures I.72; quoted in James G. Turner, One Flesh: Paradisal Marriage and Sexual Relations in the Age of Milton (New York: Oxford University Press, 1987), p. 6.
16. For a theological reading of the rhetorical appropriations of silence inHerbert's verse, see Elizabeth Clarke, "Silent Performative Words: The Language of God in Valdesso and George Herbert," Journal of Literature and Theology 5 (1991): 355-74.

17. Turner, One Flesh, p. 32.

18. All biblical citations are from the Authorised King James Version.

19. Illuminating surveys of the interpretive history of Christian erotology be found in David Carr, The Erotic Word: Sexuality, Spirituality, and the Bible (Oxford: Oxford University Press, 2003); Pierre Payer, The Bridling of Desire: Views of Sex in the Later Middle Ages (Toronto: University of Toronto Press, 1993); and Turner, One Flesh.

20. Augustine, City of God, 14.16, p. 577.

21. Quoted in Payer, The Bridling of Desire, pp. 4546.

22. Schoenfeldt, Prayer and Power, p. 258; Oxford English Dictionary Online, s.v. "pudendum," http://dictionary.oed.com (accessed January 3, 2009). All $O E D$ citations are taken from this online resource.

23. The flower's generative seed hints also at the medieval and Renaissanceequation of semen with "seed." Schoenfeldt attends to moments of priapic tumescence in other poems including "Church-monuments," "Mortification," and "H. Baptisme" (II) (pp. 244, 248).

24. OED, s.v. "bent" (1.1, accessed January 3, 2009).

25. Don Cameron Allen, “George Herbert's Sycamore," Modern Language Notes 59 (1944): 493-95.

26. Augustine, City of God, 14.11, p. 570.

27. Herbert was undoubtedly not the first to have assigned a phallic symbolism to the trees in the fallen Garden. In Pseudodoxia Epidemica, Sir Thomas Browne ascribes the phallic interpretation of the Tree of Knowledge to the speculations of Jewish Talmudists, who had debated "whether the Tree amid the Garden was not that part in the Center of the body in which was afterwards the appointment of Circumcision in Males" (quoted in Turner, One Flesh, p. 128).

28. OED, s.v. "prick" (12b, accessed January 3, 2009). For the coital meanings of the verbs "prick" and "pricking, " see Eric Partridge, Shakespeare's Bawdy (London: Routledge, 1968), p. 167. Also significant are the obsolete links between the verb "prick" and the act of musical inscription: "To write or set down (music) employing pricks or notes; (also) to write music in (a book)" (OED 20a, accessed January 3, 2009). One might argue that the musical metaphor, to which the musician 
Herbert would almost certainly have been tuned, resonates with a score of images throughout The Temple in which phallic writing instruments limn a central debate between poetry and cupidity, composition and desire - a point that my essay will often return to.

29. George Herbert, The Williams Manuscript of George Herbert's Poems: A Facsimile Reproduction, introduction by Amy M. Charles (New York: Scholars' Facsimiles and Reprints, 1977). All quotations from the Williams manuscript are from this edition.

30. Janis Lull, The Poem in Time: Reading George Herbert's Revisions of "The Church" (London: Associated University Press, 1990), p. 130.

31. Jacques Derrida, Margins of Philosophy, trans. Alan Bass (Chicago: University of Chicago Press, 1982), p. 215. For "poststructuralist" readings of Herbert's poems based on Derrida's theories of deconstruction, see Jonathan Goldberg, "The Dead Letter: Herbert's Other Voices," in Voice

Terminal Echo: Postmodernism and English Renaissance Texts (New York: Methuen, 1986), pp. 10123; and Warren M. Liew, " 'Thy word is all': Différance in George Herbert's Christian Hermeneutics," Literature and Belief 19 (1999): 191-210.

32. George Herbert, The Latin Poetry: A Bilingual Edition, trans. Mark McCloskey and Paul R. Murphy (Athens: Ohio University Press, 1965), p. 125.

33. Lull, The Poem in Time, p. 131.

34. John Calvin, Institutes of the Christian Religion, ed. John T. McNeill, trans. Ford Lewis Battles (Philadelphia: Westminster Press, 1960), 1.5.12, 1.6.3, pp. $64,73$.

35. John Milton, Paradise Lost, ed. Barbara K. Lewalski (Malden: Blackwell Publishing, 2007), Bk. 2, 1. 561.

36. Schoenfeldt, Prayer and Power, p. 243.

37. Richard Strier, Love Known: Theology and Experience in George Herbert's Poetry (Chicago: University of Chicago Press, 1983), p. 39.

38. Calvin, Institutes 1.11 .8 , p. 108. See also William Loader, Sexuality and the Jesus Tradition (Michigan: William B. Eerdmans Publishing, 2005), pp. 2731. Discussing critical biblical passages, Loader observes that both hands and feet can be euphemisms for the penis, and points out an allusion to masturbation as "adultery by hand" in Matt. 5: 29-30.

39. Lull, The Poem in Time, p. 139.

40. Izaak Walton, "The Life of Mr George Herbert," in George Herbert, The Complete English Poems, ed. John Tobin (London: Penguin, 1991), p. 280.

41. The earliest recorded appearance of "penis" in the $O E D$ is in 1578 (accessed January 3, 2009). Shakespearean studies have frequently noted the pun on pen/penis. See Eric Partridge, Shakespeare's Bawdy, p. 158; Stephen Booth, ed. Shakespeare's Sonnets (New Haven: Yale University Press, 1977), p. 270; and Hilda M. Hulme, Explorations in Shakespeare's Language: Some Problems of Lexical Meaning in the Dramatic Texts (New York: Barnes and Noble, 1963), pp. 135-36. On the sexual connotations of "spirit," see Ralph Norman, "Sexual Symbolism, Religious Language and the Ambiguity of the Spirit: Associative Themes in Anglican Poetry and Philosophy," Theology and Sexuality 13 (2007): 233-56.

42. Schoenfeldt, Prayer and Power, p. 246.

43. . On the tropological ties between Christ's circumcision and the circumcision of wit, see Jim Ellis, "The Wit of Circumcision, and Circumcision of Wit," in The Wit of Seventeenth-Century Poetry, ed. Claude J. Summers and Ted-Larry Pebworth (Columbia: University of Missouri Press, 1995), pp. 62-77.

44. Lull, The Poem in Time, p. 39.

45. Herbert, The Latin Poetry, pp. 72-73.

46. Quoted in Stephen Greenblatt, "Mutilation and Meaning," in The Body in Parts: Fantasies of Corporeality in Early Modern Europe, ed. David Hillman and Carla Mazzio (New York: Routledge, 1997), p. 223.

47. See Schoenfeldt, Prayer and Power, p. 249. For the possibility of a sexual pun on "come," see Eric Partridge, Shakespeare's Bawdy, pp. 81-2. The OED definition of the verb "come" gives "to come into bodily contact or sexual connection with" (39b, accessed June 29, 2009), citing Myles Coverdale's 1535 translation of Exodus 19:15 as the earliest instance of the Word's sexual usage: "Be ready against the third day, and no man comes at his wife."The modern meaning of "to experience sexual orgasm" appears to have made its first appearance as a slang word in 1650 (OED 17). Also pertinent to my argument are those definitions that identify "come" with the germination and growth of seeds (OED 14a, 14b, accessed June 29, 2009). As I have tried to suggest, botanical imagery is often charged with fallen sexuality throughout The Temple.

48. Schoenfeldt, Prayer and Power, p. 249; Richard Rambus, "Pleasure and Devotion: The Body of Jesus and Seventeenth-Century Religious Lyric," in Queering the Renaissance, ed. Jonathan Goldberg (Durham: Duke University Press, 1994), p. 262. Exploring the sexual 
penetration of bodies as a trope of human-divine intimacy, Rambus draws fascinating parallels between Herbert's "The Bag" and the holy lyrics of Richard Crashaw, a poet more readily associated with the ardent eroticism of Christian mysticism. For a comparison of Herbert's and Crashaw's negotiations with embodied religiosity, see James M. Bromley, "Intimacy and the Body in Seventeenth-Century Religious Devotion," Early Modern Literary Studies 11, no. 5 (2005), http://purl.oclc.org/emls/11-1/brominti.htm

49. The conflation of masculine and feminine attributes in the figures of both worshipper and worshipped evokes not only medieval discourses of a maternal Christ but the further possibility of homoerotic desire between God and (wo)man. See especially; Karma Lochrie, "Mystical Acts, Queer Tendencies," in Constructing Medieval Sexuality, ed. Karma Lochrie, Peggy McCracken, and James A. Schultz (Minneapolis: University of Minnesota Press, 1997), pp. 180-200; and Richard Rambus, Closet Devotions (Durham: Duke University Press, 1998).

50. See, for example, Costly Monuments: Representations of the Self in George Herbert's Poetry (Cambridge: Harvard University Press, 1982). Harnessing Derridean topoi to similar insights, Jonathan Goldberg sees many of Herbert's lyrics enacting "the cancellation of all propriety, of ownership, authorship, self, meaning" in Voice Terminal Echo, p. 123.

51. Jonathan Goldberg, Voice Terminal Echo, pp. 110-11. Spirited debates over the historical and religious bases of Herbert's "private ejaculations" may be found in Elizabeth Clarke, "Herbert's House of Pleasure? Ejaculations Sacred and Profane" George Herbert Journal 19 (1995): 55-71; J. Stephen Murphy, "Ejaculatory Poetics and the Writing of Ecstasy in George Herbert's 'Prayer' (I)," George Herbert Journal 24 (2000): 19-34; and Alan Rudrum, "The Problem of Sexual Reference in George Herbert's Verse," George Herbert Journal 21 (Fall 1997/spring 1998): 19-32.

52.

53. Augustine, City of God, 14.16, p. 577.

54. Booth supports the sexual meanings of "to serve" and "service",. Schoenfeldt expounds on the erotic resonances of eating in various religious and literary contexts in Prayer and Power, pp. 258-62. On the bawdy connotations of "meat," see Booth, Sonnets, p. 396; and Partridge, Bawdy, p. 147

55. The association of "eyes" with lust, seduction, and temptation in Renaissance discourses of desire has been extensively noted. See, for example, Greg Crossan, “Herbert's 'Love' (III)," Explicator 37 (1978): 41; William Loader, Sexuality and the Jesus Tradition, pp. 33-35; Sergei Lobanov-Rostovsky, "Taming the Basilisk," in The Body in Parts: Fantasies of Corporeality in Early Modern Europe, ed. David Hillman and Carla Mazzio (New York: Routledge, 1997), pp. 195-217; and Celestin John Walby, “ 'Quick-ey'd Love': Regenerate Eyes and Spiritual Body in Herbert's 'Love' (III)," George Herbert Journal 21 (fall 1997/spring1998): 58-72.

56. In a similar vein, Thomas Merrill in "Sacred Parody and the Grammar of Devotion" argues that "sacred parody" need not imply a hierarchical relationship between a poem's earthly content and its divine context, but rather an "interaction occurring [between] two structurally similar yet essentially different loves informing one another" through a sort of "linguistic incarnation" (p. 210). For a comparable reading of the "incarnation" of divine presence in the visual representation of the poem "Coloss. 3:3," see For slightly contrasting analyses of the links between phallic aggression and the rapacious intellect in "Vanitie" (I), see Schoenfeldt, Prayer and Power, p. 246; and Rudrum, "The Problem of Sexual Reference in George Herbert's Verse," pp. 19-32.

57. The phrase is from Roland Barthes, "Death of the Author," in Image, Music, Text, ed. and trans. Stephen Heath (New York: Hill and Wang, 1977).

58. Schoenfeldt, Prayer and Power, p. 263.

59. Augustine, City of God 14.23, p. 587

60. Augustine, City of God, 14.18, p. 580.

61. Turner, One Flesh, p. 35.

62. Crossan, “Herbert's 'Love' (III),” p. 41.

\section{REFERENCES}

[1] Barbara Lewalski, Protestant Poetics and the SeventeenthCentury Religious Lyric (Princeton: Princeton University Press, 1979);

[2] A Study in English Religious Literature in the Seventeenth Century (New Haven: Yale University Press, 1954);

[3] "Sacred 'Parody' of Love Poetry, and Herbert," in Essays by Rosemond Tuve: Spenser, Herbert, Milton, ed. Thomas P. Roche, Jr. (Princeton: Princeton University Press, 1970), pp. 207-51

[4] John Wall, Transformations of the Word: Spenser, Herbert, Vaughan (Athens: University of Georgia Press, 1988), pp. 224-37.

[5] Bruce Wardropper, "The Religious Conversion of Profane Poetry," in Studies in the Continental Background of Renaissance English Literature: Essays Presented to John L. 
Lievsay, ed. Dale B.J. Randall and George Walton Williams (Durham: Duke University Press, 1977), pp. 203-21

[6] Rosemond Tuve, "George Herbert and Caritas," in Essays by Rosemond Tuve: Spenser, Herbert, Milton, ed. Thomas P. Roche (Princeton: Princeton University Press, 1970), p. 181.

[7] Gerald Bruns, Modern Poetry and the Idea of Language: A Critical and Historical Study (New Haven: Yale University Press, 1974), p. 190.

[8] John Donne, The Sermons of John Donne, vol. 6, ed. Evelyn M. Simpson and George R. Potter (Berkeley: University of California Press, 195362), p. 200.

[9] John Donne, The Divine Poems, ed. Helen Gardner (Oxford: Clarendon Press, 1966), p. 27 R. Nicole, "Title of paper with the only first word capitalised," J. Name Stand. Abbrev., in press.

[10] Thomas Merrill, "Sacred Parody and the Grammar of Devotion," Criticism 23 (1981): 199.

[11] Sir Philip Sidney, An Apology for Poetry, ed. Geoffrey Shepherd (London: Nelson, 1965), p. 101.

[12] Stanley Fish, Surprised by Sin: The Reader in "Paradise Lost" (London: Macmillan, 1997), p. 106.

[13] John Savoie, "The Word Within Predicating the Presence of God in George Herbert's The Temple," George Herbert Journal 23 (Fall 1999/spring 2000): 55-64.

[14] Stanley Stewart, "Investigating Herbert Criticism," Renascence 45 (1993): 146.

[15] Mark Taylor, The Soul in Paraphrase: George Herbert's Poetics (Paris: Mouton, 1974), p. 51.

[16] Judith Dundas, “George Herbert and Divine 'Paronomasia,' " in George Herbert: Sacred and Profane, ed. Helen Wilcox and Richard Todd (Amsterdam: VU University Press, 1995), p. 81.

[17] Francis Bacon, The Works of Francis Bacon, Lord Chancellor of England, vol. 2, ed. Basil Montagu (Philadelphia: Carey and Hart, 1841), p. 91.

[18] Shakespeare's Sonnets, p. 487; and Partridge, Shakespeare's Bawdy, p. 181

[19] Stanley Fish, Self-Consuming Artifacts: The Experience of Seventeenth-Century Literature (Berkeley: University of California Press, 1972); Barbara Leah Harman

[20] Carolyn Walker Bynum, Jesus as Mother: Studies in the Spirituality of the High Middle Ages (Berkeley: University of California Press, 1982)

[21] Calvin, Institutes 1.11.8, p. 108. See also William Loader, Sexuality and the Jesus Tradition (Michigan: William B. Eerdmans Publishing, 2005), pp. 2731 